\title{
Insulin-like growth factor I reduces thyroid hormone receptors in the rat liver. Evidence for a feed-back loop regulating the peripheral thyroid hormone action
}

\author{
C G Pellizas, A H Coleoni, M E Costamagna, M Di Fulvio and \\ A M Masini-Repiso \\ Departamento de Bioquímica Clínica, Facultad de Ciencias Químicas, Universidad Nacional de Córdoba, Córdoba, Argentina \\ (Requests for offprints should be addressed to C G Pellizas, Departamento de Bioquímica Clínica, Facultad de Ciencias Químicas, Universidad Nacional de \\ Córdoba, Agencia Postal 4, Casilla de Correo 61, 5000 Córdoba, Argentina)
}

\begin{abstract}
Tri-iodothyronine $\left(\mathrm{T}_{3}\right)$ is known to be involved in the regulation of the growth hormone $(\mathrm{GH})$-insulin-like growth factor I (IGF-I) axis. In previous studies we demonstrated that IGF-I and GH reduced the metabolic response to $\mathrm{T}_{3}$ measured as the activity of two $\mathrm{T}_{3^{-}}$ dependent enzymes, mitochondrial $\alpha$-glycerophosphate dehydrogenase $(\alpha-G P D)$ and cytosolic malic enzyme (ME) in cultured rat liver cells. In this study we analysed in vivo the effect of IGF-I administered to rats on the activity of $\alpha$-GPD and ME. IGF-I $(240 \mu \mathrm{g} / 100 \mathrm{~g}$ body weight $(\mathrm{BW})$ every $12 \mathrm{~h}$ for $48 \mathrm{~h}$ ) significantly diminished $\alpha$-GPD $(P<0 \cdot 01)$ and ME $(P<0 \cdot 05)$ activities. Serum basal glucose concentration was not significantly modified $12 \mathrm{~h}$ after the administration of recombinant human IGF-I (240 and $480 \mu \mathrm{g} / 100 \mathrm{~g} \mathrm{BW}$ every $12 \mathrm{~h}$ for $48 \mathrm{~h}$ ). Under similar conditions, no significant change in serum total thyroxine $\left(\mathrm{TT}_{4}\right)$ concentration was observed, although free thyroxine $\left(\mathrm{FT}_{4}\right)$ was diminished $(P<0 \cdot 02)$ and total $\mathrm{T}_{3}$ $\left(\mathrm{TT}_{3}\right)$ was increased $(P<0 \cdot 03)$. To explore the partici-
\end{abstract}

pation of the nuclear thyroid hormone receptor (THR) in the mechanism of IGF-I action we measured the maximal binding capacity and the affinity constant $\left(K_{\mathrm{a}}\right)$ of THR by Scatchard analysis, and concentrations of messenger RNAs (mRNAs) that code for the isoforms of THR present in the liver $\left(\beta_{1}, \alpha_{1}\right.$ and $\left.\alpha_{2}\right)$ by Northern blot. IGF-I $(240 \mu \mathrm{g} / 100 \mathrm{~g} \mathrm{BW}$ every $12 \mathrm{~h}$ for $48 \mathrm{~h})$ significantly reduced maximal binding capacity to $37 \%$ of the control value $(P<0 \cdot 01)$ without changes in the $K_{\mathrm{a}} \cdot \beta_{1}, \alpha_{1}$ and $\alpha_{2}$ THR mRNAs were significantly reduced $(P<0 \cdot 01)$ by 120-480 $\mu \mathrm{g} / 100 \mathrm{~g}$ BW IGF-I administration every $12 \mathrm{~h}$ for $48 \mathrm{~h}$. Time-course studies indicated that this effect was obtained $12 \mathrm{~h}$ after the administration of $240 \mu \mathrm{g} / 100 \mathrm{~g}$ BW IGF-I $(P<0 \cdot 05)$. These results indicate that IGF-I administration to rats diminishes the metabolic thyroid hormone action in the liver by a mechanism that involves, at least in part, a reduction in the number of THRs and in their level of expression.

Journal of Endocrinology (1998) 158, 87-95

\section{Introduction}

The participation of 3,5,3'-tri-iodothyronine $\left(\mathrm{T}_{3}\right)$ in the regulation of the growth hormone $(\mathrm{GH})$-insulin-like growth factor I (IGF-I) axis is well established (RodriguezArnao et al. 1993). $T_{3}$ is required for normal GH gene expression and thyroid hormone responsive elements have been identified in the GH gene promoter (Koenig et al. 1987, DeGroot et al. 1988, Williams \& Brent 1995). Pituitary GH secretion and GH mRNA level are reduced in hypothyroid rats and restored to normal after treatment with $\mathrm{T}_{3}$ (Hervas et al. 1975, Nyborg et al. 1985). In primary culture of pituitary cells, IGF-I, the major mediator of growth promoting effects of $\mathrm{GH}$, inhibits $\mathrm{T}_{3}$ induction of $\mathrm{GH}$ mRNA and GH release (Melmed \& Yamashita 1986). In contrast, in the perfused rat liver, physiological doses of $\mathrm{T}_{3}$ stimulate the synthesis and release of IGF-I (Ikeda et al. 1991). In hypothyroid rats, serum IGF-I concentration and IGF-I gene expression in liver are reduced (Harakawa et al. 1990).

The introduction of recombinant GH and IGF-I for the treatment of growth disorders has renewed interest in the study of the effect of GH and IGF-I on thyroid function. The impact of administration of $\mathrm{GH}$ to normal and GH-deficient patients on thyroid function has yielded conflicting results. Diverse reports have described a decrease in thyroid uptake of iodine-125, serum thyrotrophin (TSH) and serum thyroxine $\left(\mathrm{T}_{4}\right)$ and an increase in serum $\mathrm{T}_{3}$ after administration of $\mathrm{GH}$ (Grunfeld et al. 1988, Jorgensen et al. 1989, 1994), whereas IGF-I administered to Laron-type dwarfs and healthy individuals induces a decrease in TSH and free $T_{4}$, with no change in the $T_{3}$ serum concentration (Klinger et al. 1992). 
However, the impact of GH and IGF-I on specific metabolic responses to $T_{3}$ in target tissues has received scant attention. In previous studies (Pellizas et al. 1996), we demonstrated that IGF-I and GH incorporated to cultured rat liver cells induced a time- and dose-dependent reduction in the activity of mitochondrial $\alpha$-glycerophosphate dehydrogenase $(\alpha-G P D)$ and cytosolic malic enzyme (ME), two specific tissue markers of thyroid hormone action (Oppenheimer et al. 1995). Evidence that the GH effect was mediated by IGF-I was also obtained (Pellizas et al. 1996).

Although $\mathrm{T}_{3}$ may exert its effects via different cellular loci, its major effect is the transcriptional regulation of target genes mediated by nuclear thyroid hormone receptors (THR) (Yen \& Chin 1994). The liver represents an important target tissue for thyroid hormone action, with ligand binding studies suggesting abundant expression of high affinity receptors for $\mathrm{T}_{3}$ (Brent 1994). The cloning of specific THR complementary DNA (cDNA) led to evidence of the expression of $\alpha_{1}, \alpha_{2}$ and $\beta_{1}$ THR messenger ribonucleic acids (mRNAs) in rat liver, although concentrations of these mRNAs were low compared with those present in other tissues (Schwartz et al. 1992). More recently, the development of specific antibodies has provided evidence for abundant expression of $\alpha_{1}, \alpha_{2}$ and $\beta_{1}$ THR proteins in the rat liver (Chamba et al. 1996).

Because THR are decisive in the initial steps of thyroid hormone action, we investigated putative modifications at the THR level that could explain the diminished metabolic response to $T_{3}$ induced by IGF-I. Results from our previous work provided evidence that the effect of IGF-I could be mediated by a reduction in the number of THRs, as the maximal $\alpha$-GPD and ME activities attained after addition of $\mathrm{T}_{3}$ to the liver cell culture in a concentration high enough to saturate the THRs fully, were significantly lower in the group pre-exposed to IGF-I (Pellizas et al. 1996).

In the present study using an in vivo model, we were able to induce a reduction of liver $\alpha-G P D$ and ME activities by the administration of IGF-I to normal rats. We also explored the mechanism of IGF-I action on the specific metabolic response to $\mathrm{T}_{3}$ by measuring the effect of IGF-I on the maximal binding capacity and the affinity constant $\left(K_{\mathrm{a}}\right)$ of THR, in addition to the levels of the mRNAs that code for the THR isoforms in the liver.

\section{Materials and Methods}

\section{Materials}

Recombinant human IGF-I (rhIGF-I) was from Genentech Inc, San Francisco, CA, USA, $\left[{ }^{125} \mathrm{I}\right] \mathrm{T}_{3}$ and $\left[\alpha^{32} \mathrm{P}\right]$ ATP from Du Pont NEN (Boston, MA, USA). Nylon membranes (charge modified, $0.45 \mu \mathrm{m}$ pore size) were from Sigma Chemical Co., St Louis, MO, USA, hybridization bags and EcoRI from Gibco BRL,
Gaithersburg, MD, USA. The DNA labelling kit (Premea-gene Labeling System) was from Promega Corp., Madison, WI, USA. The radiographic films were from Eastman Kodak, Rochester, NY, USA and the intensifying screens from Amersham International plc, Amersham, Buckinghamshire, UK. The plasmid Bluescript SK+ $\mathrm{TR} \beta 1(\mathrm{pBSK}+\beta 1)$ was generously donated by R. Koenig, Department of Internal Medicine, Endocrinology and Metabolism Division, The University of Michigan Medical Center, Ann Arbor, MI, USA. All chemicals were of reagent grade.

\section{Animals and rhIGF-I treatment}

Adult male Wistar rats $(250 \pm 50 \mathrm{~g})$ were given free access to a balanced diet and tap water, and maintained under a $12 \mathrm{~h}$ light : $12 \mathrm{~h}$ darkness cycle. Rats were injected s.c. with vehicle $(0.15 \mathrm{M} \mathrm{NaCl})$ or rhIGF-I every $12 \mathrm{~h}$ for different periods of time. Rats were lightly anaesthetized, killed by cervical dislocation, and the liver removed and processed for different purposes. Animal procedures were in compliance with the Guidelines on the Handling and Training of Laboratory Animals published by the Universities Federation for Animal Welfare, and the local Institutional Animal Care Committee.

The doses of rhIGF-I $(60-480 \mu \mathrm{g} / 100 \mathrm{~g} \mathrm{BW}$ every $12 \mathrm{~h}$ ) were selected on the basis of previous reports indicating that a dose of $320 \mu \mathrm{g} / 100 \mathrm{~g} \mathrm{BW}$ per day was able to induce IGF-I-dependent effects (Hinton et al. 1995, Lo et al. 1995).

\section{Isolation of mitochondrial, cytosolic and nuclear fractions}

The procedure was similar to that described previously, with slight modifications (Bernal et al. 1978a). In brief, liver tissue $(1 \mathrm{~g})$ homogenized in $0 \cdot 32 \mathrm{M}$ sucrose $-1 \mathrm{mM}$ $\mathrm{MgCl}_{2}$ with a Teflon-glass motor-driven tissue grinder was centrifuged at $700 \mathrm{~g}$ to obtain the crude nuclear pellet. The supernatant was centrifuged at $8500 \mathrm{~g}$ for $10 \mathrm{~min}$ for the preparation of the mitochondrial fraction. The $8500 \mathrm{~g}$ pellet was washed once with $0 \cdot 125 \mathrm{M}$ potassium phosphate buffer (KBP), pH 7.5. The pellet containing the mitochondrial fraction was resuspended in $3 \mathrm{ml} \mathrm{KBP}$. The initial $8500 \mathrm{~g}$ supernatant was centrifuged at $105000 \mathrm{~g}$ to obtain the cytosolic fraction.

The crude nuclear pellet was resuspended in $2.3 \mathrm{M}$ sucrose-1 $\mathrm{mM} \quad \mathrm{MgCl}_{2}-2 \mathrm{mM}$ dithiothreitol (DTT)$0 \cdot 1 \mathrm{mM}$ phenylmethylsulphonyl fluoride and centrifuged at $114000 \mathrm{~g}$ for $30 \mathrm{~min}$ in a Beckman 50.1 SW rotor. The pellet was resuspended in $0.32 \mathrm{M}$ sucrose- $1 \mathrm{mM} \mathrm{\textrm {MgCl } _ { 2 } -}$ $1 \mathrm{mM} \mathrm{CaCl}_{2-}-20 \mathrm{mM}$ Tris-2 mM DTT, pH 7.85 $(\mathrm{SMCT})$ and $0.5 \%$ Triton $\mathrm{X}-100$. After $1 \mathrm{~min}$ at $0{ }^{\circ} \mathrm{C}$, the tube was centrifuged at $250 \mathrm{~g}$ for $3 \mathrm{~min}$. The pellet was washed once with SMCT. The final pellet containing the purified nuclear fraction was resuspended in $10 \mathrm{ml} 0.32 \mathrm{M}$ sucrose-1 mM MgCl $2-20 \mathrm{mM}$ Tris, $\mathrm{pH} 7 \cdot 85$ (SMT). 
Enzyme activity assays

$\alpha$-Glycerophosphate dehydrogenase [EC 1.1.99.5; sn-glycerol-3-phosphate: (acceptor) oxidoreductase] was assayed in the mitochondrial fraction by the method of Lee \& Lardy (1965) and expressed as $\Delta \mathrm{A} / \mathrm{min}$ per mg DNA. Malic enzyme [EC 1.1.1.40; L-malate-NADP ${ }^{+}$oxidoreductase (decarboxylating)] was assayed in the cytosolic fraction by the method of Hsu \& Lardy (1969) and expressed as $\mathrm{U} / \mathrm{mg}$ DNA. One unit $(\mathrm{U})$ was defined as the amount of the enzyme needed to catalyse the reduction of $1 \mathrm{nmol} \mathrm{NADP} / \mathrm{min}$ using an extinction coefficient for $\mathrm{NADPH}$ of $\mathrm{E}_{340}^{\mathrm{mmol} / \mathrm{l}}=6 \cdot 3$ (Mariash et al. 1980).

The DNA content was evaluated in the total cellular homogenate and in the purified nuclear fraction by the method of Burton (1956).

\section{$\left[{ }^{125} \mathrm{I}\right] \mathrm{T}_{3}$-binding studies}

The maximal binding capacity and the $K_{\mathrm{a}}$ of THR were measured in isolated nuclei as described previously (Bernal et al. 1978b). Briefly, nuclei (200-300 $\mu \mathrm{g}$ DNA/tube) were incubated in SMT with $7 \cdot 8 \times 10^{-11}-2.5 \times 10^{-9} \mathrm{M}$ $\left[{ }^{125} \mathrm{I}_{\mathrm{T}} \mathrm{T}_{3}(2200 \mathrm{Ci} / \mathrm{mmol})\right.$. To assess non-specific binding, tubes containing $2.9 \times 10^{-7} \mathrm{M} \mathrm{T}_{3}$ were run in parallel. After $2 \mathrm{~h}$ incubation at $20 \pm 2{ }^{\circ} \mathrm{C}$, the nuclei were ice-cooled and centrifuged at $1000 \boldsymbol{g}$ for $10 \mathrm{~min}$. The nuclear pellets were washed twice in SMCT plus $0.5 \%$ Triton X-100 and the radioactivity in the pellet measured. The amount of receptors released to the medium during the incubation period (Bernal \& DeGroot 1977) was measured in the $1000 \mathrm{~g}$ supernatants by the resin test. Total $\mathrm{T}_{3}$ binding was calculated by Scatchard analysis (Scatchard 1949) from the $\left[{ }^{125} \mathrm{I}\right] \mathrm{T}_{3}$ bound to the nuclear pellet and to the supernatants (resin test).

\section{Total RNA extraction}

Total RNA was prepared by the one-step acidguanidinium method described by Chomczynski \& Sacchi (1987). In brief, $0.5 \mathrm{~g}$ liver was homogenized in $5 \mathrm{ml}$ denaturing solution (4 M guanidinium isothiocyanate, $25 \mathrm{mM}$ sodium citrate $\mathrm{pH} 7 \cdot 0,0 \cdot 5 \% \mathrm{~N}$-lauroyl sarcosine and $0 \cdot 1 \% \beta$-mercaptoethanol). After phenol-chloroformisoamyl alcohol $(50: 49: 1)$ extraction, RNA was precipitated in isopropanol, recovered by centrifugation and washed in 75\% ethanol. After a further extraction, precipitation and wash, the RNA was dissolved in diethyl pyrocarbonate-treated water and quantified and checked for purity by spectrophotometry at 260 and $280 \mathrm{~nm}$.

\section{Northern blot}

Forty micrograms total RNA were electrophoresed in 1\% agarose gel containing $0.66 \mathrm{M}$ formaldehyde (Fourney et al. 1988). This agarose concentration allowed a good separation of the three THR mRNA species: $\beta_{1}, 6 \cdot 0 \mathrm{~kb}$; $\alpha_{1}, 5.0 \mathrm{~kb} ; \alpha_{2}, 2.6 \mathrm{~kb}$ (Strait et al. 1990). The gel was stained with ethidium bromide to visualize ribosomal RNA (rRNA). After electrophoresis, RNAs were transferred to a nylon membrane.

The membranes were incubated in prehybridization solution containing $30 \%$ deionized formamide$5 \times$ Denhart's solution $(0.1 \%$ Ficoll type $400-0 \cdot 1 \%$ albumin- $0 \cdot 1 \%$ polyvinylpirrolidone (PVP) $)-5 \times \mathrm{SSPE}$ $\left(0.75 \mathrm{M} \mathrm{NaCl}-0.05 \mathrm{M} \mathrm{NaH}_{2} \mathrm{PO}_{4}-5 \mathrm{mM}\right.$ EDTA $)-1 \%$ SDS-200 $\mu \mathrm{g} / \mathrm{ml}$ DNA from herring testes, for $5 \mathrm{~h}$ at $42{ }^{\circ} \mathrm{C}$ in hybridization bags. Hybridizations with the probe were performed for $48 \mathrm{~h}$ at the same temperature. The entire $\mathrm{pBSK}^{+} \beta_{1}$ THR cDNA (Koenig et al. 1988) linearized with EcoRI was used as hybridization probe for Northern blots. The entire cDNA is approximately $1.4 \mathrm{~kb}$, and includes the full coding sequence. As the DNA and ligand binding domain are very similar in $\operatorname{THR} \alpha$ and $\operatorname{THR} \beta$, this cDNA has been used as a common probe for all THR isoforms (Koenig et al. 1988). To ensure an even loading, the same blots were hybridized using the entire pBR 322 with an 18S rRNA genomic probe. The probes were labelled by the random primer technique with $\left[\alpha-{ }^{32} \mathrm{P}\right]$ deoxy-ATP $(3000 \mathrm{Ci} / \mathrm{mmol})$. The specific activity of the labelled probes ranged from $2.6 \times 10^{9}-3.9 \times 10^{9}$ d.p.m./ $\mu$ g DNA. After hybridization, blots were washed in $2 \times \mathrm{SSC}(0.3 \mathrm{M} \mathrm{NaCl}-0.015 \mathrm{M}$ sodium citrate $)-1 \%$ SDS for $20 \mathrm{~min}$ at room temperature, followed by $2 \times \mathrm{SSC}-1 \% \mathrm{SDS}$ for $20 \mathrm{~min}$ at $55^{\circ} \mathrm{C}, 1 \times \mathrm{SSC}-1 \% \mathrm{SDS}$ for $20 \mathrm{~min}$ at $55^{\circ} \mathrm{C}$ and $0.2 \times \mathrm{SSC}-1 \%$ SDS for $20 \mathrm{~min}$ at $55{ }^{\circ} \mathrm{C}$. The membranes were exposed to Kodak X-Omat film at $-70{ }^{\circ} \mathrm{C}$ with intensifying screens, for 20 days in the case of the THR probe, and for $6 \mathrm{~h}$ in the case of the $18 \mathrm{~S}$ rRNA probe. The bands were quantified densitometrically (Shimadzu Dual-Wavelength Chromato Scanner CS-930) at $500 \mathrm{~nm}$ and the levels of THR mRNA expressed as the absorbance of the THR signals normalized with that of the 18S rRNA in the same lane.

\section{Glucose determination}

The serum glucose concentration was evaluated in samples collected $12 \mathrm{~h}$ after the last rhIGF-I dose ( $48 \mathrm{~h}$ treatment), using a commercial kit (Enzymatic glycaemia, Wiener lab, Rosario, Argentina).

\section{Serum thyroid hormone concentrations}

Serum concentration of total $\mathrm{T}_{4}\left(\mathrm{TT}_{4}\right)$, free $\mathrm{T}_{4}\left(\mathrm{FT}_{4}\right)$ and total $\mathrm{T}_{3}\left(\mathrm{TT}_{3}\right)$ were measured in samples collected $12 \mathrm{~h}$ after the last rhIGF-I dose ( $48 \mathrm{~h}$ treatment) by radioimmunoassay using commercial kits (Diagnostic Products Corporation, Los Angeles, CA, USA). Each sample was assayed in duplicate. Intra- and interassay coefficients of variation were $3 \cdot 3 \%$ and $8 \cdot 1 \%$ for $\mathrm{TT}_{4}, 5 \%$ and $8 \%$ for $\mathrm{FT}_{4}$, and $6 \cdot 1 \%$ and $9 \cdot 5 \%$ for $\mathrm{TT}_{3}$. 


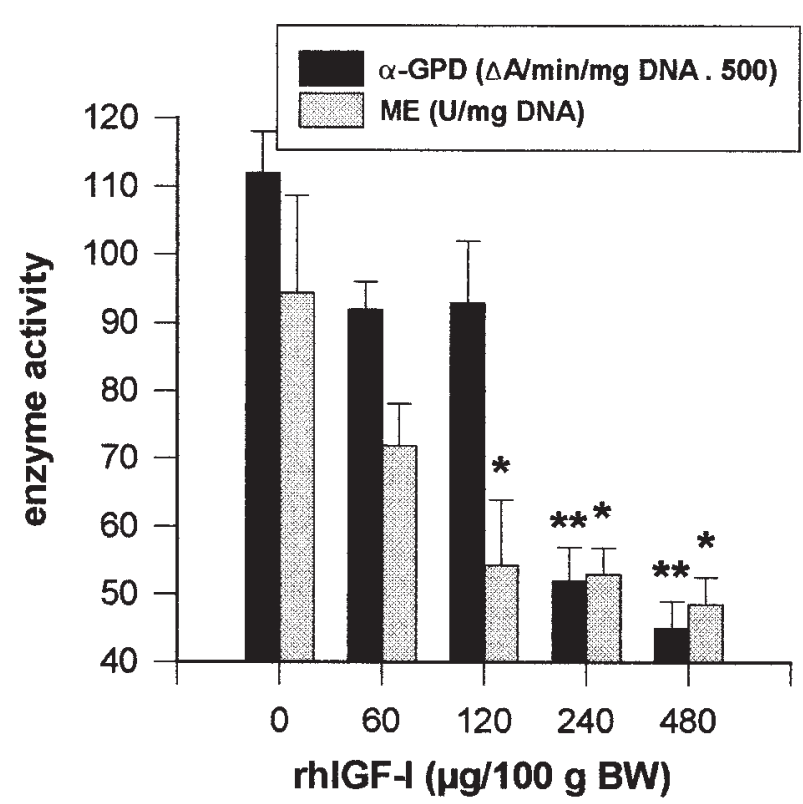

Figure 1 Effect of rhlGF-I administration to rats on liver $\alpha$-GPD and ME activities. rhIGF-I was administered s.c. every $12 \mathrm{~h}$ for $48 \mathrm{~h}$. Results are expressed as means \pm S.E.M. Eight samples were analysed from each individual animal in each group, in two separate experiments; each analysis was performed at least in duplicate. ${ }^{*} P<0 \cdot 05,{ }^{*} P<0 \cdot 01$ compared with the control group by one-way ANOVA followed by Student-Newman-Keuls test.

\section{Statistical analysis}

Analysis of multiple intergroup differences in each experiment was conducted by one-way analysis of variance (ANOVA) followed by the Student-Newman-Keuls test. Comparisons between two groups were made using the Student's $t$-test. $P<0 \cdot 05$ was considered statistically significant.

\section{Results}

\section{$a-G P D$ and ME activities}

Figure 1 shows the effect of increasing doses of rhIGF-I, administered to rats during $48 \mathrm{~h}$, on the activity of $\alpha-\mathrm{GPD}$ and ME. A reduction in ME activity was observed after $120 \mu \mathrm{g} / 100 \mathrm{~g} \mathrm{BW}$ rhIGF-I $(P<0 \cdot 05)$. A similar effect on $\alpha-\mathrm{GPD}$ activity was obtained by the administration of $240 \mu \mathrm{g} / 100 \mathrm{~g} \mathrm{BW}(P<0 \cdot 01)$.

\section{Serum glucose concentration}

Recombinant human IGF-I treatment every $12 \mathrm{~h}$ for $48 \mathrm{~h}$ did not induce significant changes in basal serum glucose concentration $12 \mathrm{~h}$ after the last IGF-I injection (mean \pm s.D. values $(\mathrm{mM})$ : control $6.78 \pm 1 \cdot 56$; rhIGF-I $(240 \mu \mathrm{g} / 100 \mathrm{~g} \mathrm{BW}) 6 \cdot 72 \pm 0 \cdot 61 ;$ rhIGF-I $(480 \mu \mathrm{g} / 100 \mathrm{~g}$ BW) $7 \cdot 17 \pm 0 \cdot 72 ; n=6$ in each group, Student's $t$-test).
Table 1 Effect of administration of rhlGF-I on serum thyroid hormone concentrations in rats. rhIGF-I $(240 \mu \mathrm{g} / 100 \mathrm{~g} \mathrm{BW})$ was administered s.c. every $12 \mathrm{~h}$ for $48 \mathrm{~h}$. Results are expressed as means \pm S.D. for duplicate determinations. Data are from a representative experiment from a total of three with similar results

\begin{tabular}{|c|c|c|c|}
\hline & $\begin{array}{l}\mathbf{T}_{4} \\
(\mu \mathrm{g} / \mathrm{dl})\end{array}$ & $\begin{array}{l}\mathbf{F T}_{\mathbf{4}} \\
(\mathrm{ng} / \mathrm{dl})\end{array}$ & $\begin{array}{l}\mathbf{T T}_{3} \\
(\mathrm{ng} / \mathrm{dl})\end{array}$ \\
\hline Control & $\begin{array}{l}5 \cdot 6 \pm 1 \cdot 3 \\
(n=9)\end{array}$ & $\begin{array}{l}1 \cdot 59 \pm 0 \cdot 32 \\
(n=8)\end{array}$ & $\begin{array}{l}59 \pm 8 \\
(n=7)\end{array}$ \\
\hline rhIGF-I & $\begin{array}{l}4 \cdot 6 \pm 1 \cdot 1 \\
(n=11)\end{array}$ & $\begin{array}{l}1 \cdot 12 \pm 0 \cdot 35^{*} \\
(n=8)\end{array}$ & $\begin{array}{l}72 \pm 9 * * \\
(n=5)\end{array}$ \\
\hline
\end{tabular}

${ }^{*} P<0 \cdot 02,{ }^{* *} P<0.03$ compared with control group (Student's $t$-test).

\section{Serum thyroid hormone concentrations}

The changes in circulating iodothyronines after rhIGF-I administration every $12 \mathrm{~h}$ for $48 \mathrm{~h}$ are shown in Table 1 . $\mathrm{TT}_{4}$ concentrations tended to decrease with rhIGF-I treatment, but this failed to reach statistical significance $(P=0 \cdot 09)$. In contrast, rhIGF-I treatment induced a reduction in $\mathrm{FT}_{4}$ to $70 \%$ of the control value $(P<0 \cdot 02)$, whereas there was a $22 \%$ increase in $\mathrm{TT}_{3}$ compared with the control value $(P<0 \cdot 03)$.

\section{$\left[{ }^{125} I\right] T_{3}$ binding}

The effect of rhIGF-I on the THR is shown in Fig. 2 and Table 2. The administration of rhIGF-I $(240 \mu \mathrm{g} / 100 \mathrm{~g}$ $\mathrm{BW}$ ) every $12 \mathrm{~h}$ for $48 \mathrm{~h}$ induced a significant reduction in the maximal binding capacity of THR ( $37 \%$ of control), whereas no significant changes were detected in the $K_{\mathrm{a}}$.

As previously reported (Bernal et al. 1978b), in both groups (control and rhIGF-I treated), the $K_{\mathrm{a}}$ of THR was greater in the supernatant from the 'resin test' than in the nuclear pellet (supernatant/nuclear pellet ratio, control: 1·4, rhIGF-I treated: 1·6). However the maximal binding capacity of THR was greater in the nuclear pellet than in the supernatant (nuclear pellet/supernatant ratio, control: $1 \cdot 4$, rhIGF-I treated: $1 \cdot 5)$.

The shape of the Scatchard plot from the control group did not indicate the presence of two different sets of sites for $\mathrm{T}_{3}$ binding (high and low affinity), as the Hill coefficient (De Lean \& Rodbard 1979) was 1.4 for this group.

\section{THR $m R N A s$}

The levels of liver THR mRNA isoforms $\left(\beta_{1}, \alpha_{1}\right.$ and $\left.\alpha_{2}\right)$ after administration of rhIGF-I $(120-480 \mu \mathrm{g} / 100 \mathrm{~g} \mathrm{BW}$ for $48 \mathrm{~h}$ ) are shown in Fig. 3. A significant reduction in $\beta_{1}$, $\alpha_{1}$ and $\alpha_{2}$ THR mRNAs was observed after the injection of $120 \mu \mathrm{g} / 100 \mathrm{~g} \mathrm{BW}$ rhIGF-I. THR mRNAs were at the lowest level of detection after 240 and $480 \mu \mathrm{g} / 100 \mathrm{~g} \mathrm{BW}$ rhIGF-I. 


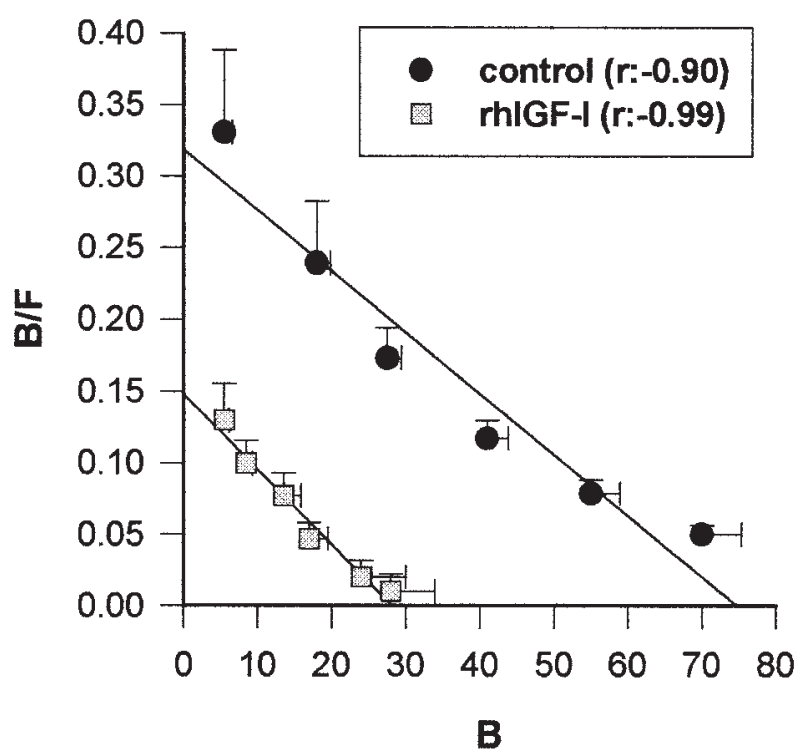

Figure 2 Scatchard plot of specific liver nuclear $\left[{ }^{125} \mathrm{I}\right] \mathrm{T}_{3}$ binding in control rats or rats treated with rhIGF-I $(240 \mu \mathrm{g} / 100 \mathrm{~g}$ BW every $12 \mathrm{~h}$ for $48 \mathrm{~h}$ ). Plots were drawn by least squares computation. $B$, bound $T_{3}$ (fmol/100 $\mu \mathrm{g} D N A$ ); $B / F$, ratio of bound $T_{3}$ to free $T_{3}$. Data are from a representative experiment from a total of two with similar results. Results are expressed as means \pm S.D. Seven samples were analysed from each individual animal in each group. Maximal binding capacity and $K_{\mathrm{a}}$ values are given in Table 2 .

Results of time-course studies of the effect of rhIGF-I $(240 \mu \mathrm{g} / 100 \mathrm{~g} \mathrm{BW})$ on THR mRNAs are indicated in Fig. 4. A significant reduction in $\beta_{1}, \alpha_{1}$ and $\alpha_{2}$ THR mRNAs concentrations was registered after $12 \mathrm{~h}$ of rhIGF-I treatment and the values were at the lowest level of detection after $24 \mathrm{~h}$.

The difference between the absorbance ratio for $\alpha_{1}$ THR mRNA from control animals in Fig. 3 (zero dose of rhIGF-I) and Fig. 4 (zero time) is not of significance, because a wide range of $\beta_{1}$ THR mRNA $/ \alpha_{1}$ THR mRNA ratios has been reported previously (Strait et al. 1990).

\section{Discussion}

The present study demonstrated that the administration of rhIGF-I to normal rats resulted in a diminished metabolic response to $\mathrm{T}_{3}$ in the liver, evaluated as the activity of $\alpha$-GPD and ME, two $\mathrm{T}_{3}$-responsive enzymes (Oppenheimer et al. 1995). This finding is in accordance with our previous results obtained in an in vitro system of cultured rat liver cells (Pellizas et al. 1996).

The doses of rhIGF-I that we used in this study were substantially greater than the sustitutive doses used in growth disorders in children (Klinger et al. 1992). However, serum IGF-I concentration in adult normal rats is about eightfold greater than that in human beings
Table 2 Effect of administration of rhlGF-I on the maximal binding capacity $(\mathrm{MBC})$ and affinity constant $\left(K_{\mathrm{a}}\right)$ of liver nuclear thyroid hormone receptors in rats. rhIGF-I $(240 \mu \mathrm{g} / 100 \mathrm{~g} \mathrm{BW})$ was administered s.c. every $12 \mathrm{~h}$ for $48 \mathrm{~h}$. Values were obtained from Fig. 2 and expressed as means \pm S.D. Seven samples were analysed from individual animals in each group

\begin{tabular}{lll} 
& $\begin{array}{l}\text { MBC } \\
\left(\mathrm{fmol} \mathrm{T}_{3} / 100 \mu \mathrm{g} \text { DNA }\right)\end{array}$ & $\begin{array}{l}\boldsymbol{K}_{\mathbf{a}} \\
\left(\mathrm{nM}^{-1}\right)\end{array}$ \\
$\begin{array}{l}\text { Control } \\
\text { rhIGF-I }\end{array}$ & $\begin{array}{l}73 \cdot 12 \pm 14 \cdot 07 \\
27 \cdot 30 \pm 2 \cdot 50^{*}\end{array}$ & $2 \cdot 19 \pm 0 \cdot 77$ \\
\hline
\end{tabular}

${ }^{*} P<0 \cdot 01$ compared with the control group (Student's $t$-test).

(Yamamoto et al. 1991, Nanto-Salonen et al. 1993). Moreover, the lack of effect of IGF-I on the animals' behaviour or on glucose concentrations, suggests that the doses administered to rats may be considered to be in a physiological rather than a pharmacological range (Jones \& Clemmons 1995).

The mechanism by which IGF-I reduced $\alpha-$ GPD and ME activities seems to be mediated by the type I IGF receptor. Although a lack of functional type I IGF receptors has been reported in rat hepatocytes (Massague \& Czech 1982, Jaeggi-Groisman et al. 1990), other authors have reported their presence in male (Gruppuso et al. 1991) and female (Venkatesan \& Davidson 1990) adult rat liver. Moreover, mRNA coding for IGF-I receptors has been reported recently (Lemmey et al. 1997). Other IGF-I-mediated effects have also been reported in the rat liver (Gosteli-Peter et al. 1994, Raper et al. 1995). In contrast, a possible crossreaction of infused IGF-I with the structurally similar liver insulin receptor would be expected to enhance, rather than suppress, the activity of a-GPD and ME (Wilson \& McMurray 1981). In addition, although IGF-I is able to reduce insulin serum concentrations (Kolaczynski \& Caro 1994), it seems not to be an explanation for the diminished liver $\mathrm{T}_{3}$ response, as this effect was also observed in rat liver cells cultured in a medium containing a fixed concentration of insulin (Pellizas et al. 1996). The involvement of IGF-II/ mannose-6-phosphate receptors in the effect of IGF-I is highly unlikely, as the affinity of these receptors for IGF-I is very low (Jones \& Clemmons 1995).

The changes in serum thyroid hormone concentrations induced by IGF-I administration are in accordance with previous results obtained after administration of $\mathrm{GH}$ to normal and GH-deficient human beings (Grunfeld et al. 1988, Jorgensen et al. 1994). The reduction in $\mathrm{FT}_{4}$ concentrations with a concomitant increase in $\mathrm{TT}_{3}$ induced by IGF-I treatment, suggests an enhanced conversion of $T_{4}$ to $T_{3}$. However, short-term administration of IGF-I to normal adults and Laron-type dwarfs resulted in a reduction in $\mathrm{FT}_{4}$ but failed to augment $\mathrm{TT}_{3}$ concentrations (Klinger et al. 1992). Nevertheless, the changes in serum thyroid hormone concentrations induced by IGF-I 
A
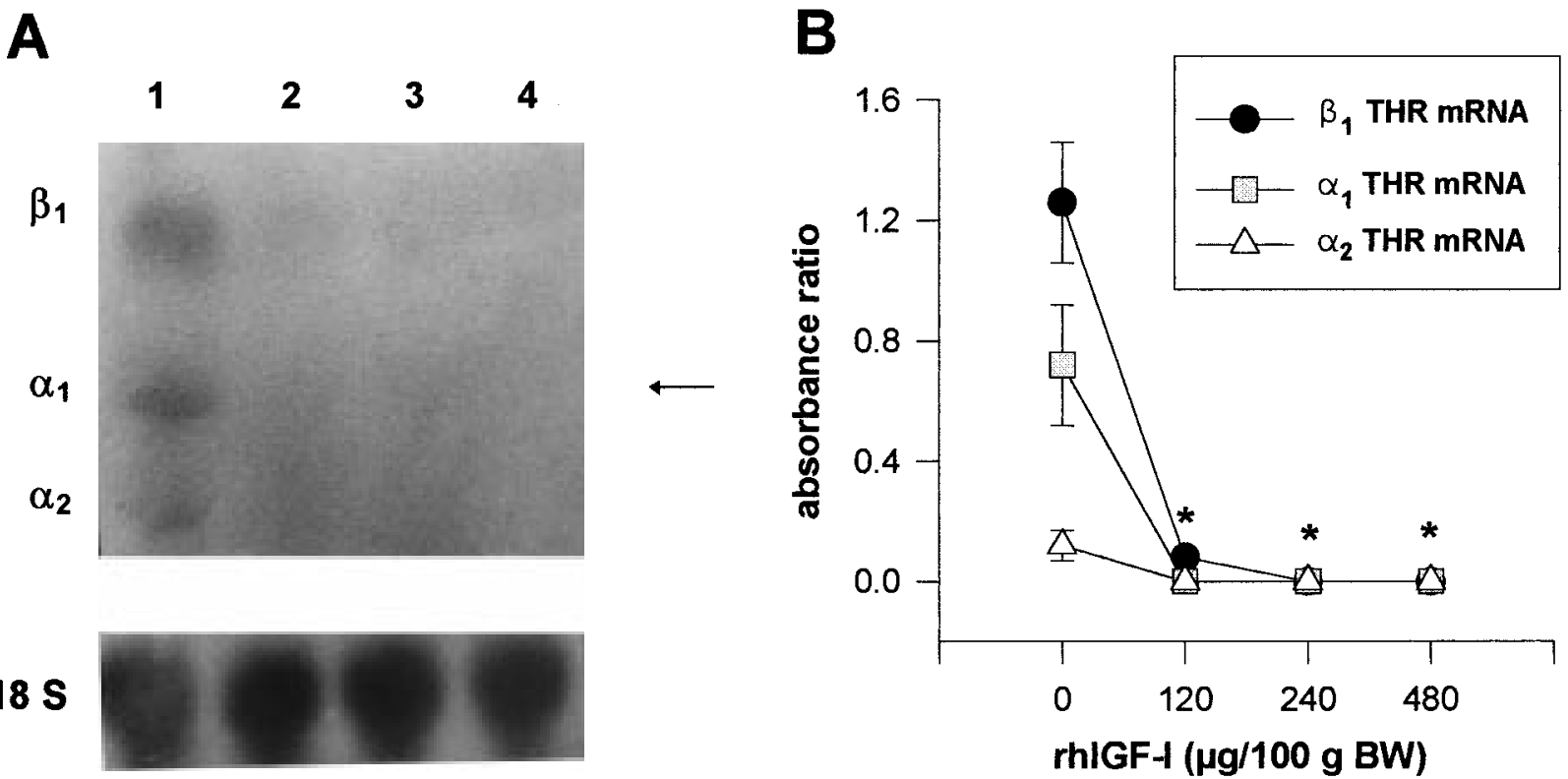

Figure 3 (A) Northern blot of liver $\beta_{1}, \alpha_{1}$, and $\alpha_{2}$ THR mRNAs after administration of rhIGF-I: lane 1, control; lane 2, $120 \mu$ g; lane 3, $240 \mu \mathrm{g}$; lane 4, $480 \mu \mathrm{g} / 100 \mathrm{~g}$ BW every $12 \mathrm{~h}$ for $48 \mathrm{~h}$. Forty micrograms total RNA were applied to each lane. Blots were hybridized with THR (upper panel) and 18S rRNA probes (lower panel). Arrow indicates the 28S rRNA marker. (B) Densitometric analysis of Northern blots. Data are given as the ratio between the absorbance of each THR-specific signal and the absorbance of the 18S rRNA signal in the same lane. Data are from a representative experiment from a total of three with similar results. Results are expressed as means \pm S.D. Three samples were analysed from each individual animal in each group. ${ }^{*} P<0 \cdot 01$ compared with the control group by one-way ANOVA followed by the Student-Newman-Keuls test.

A
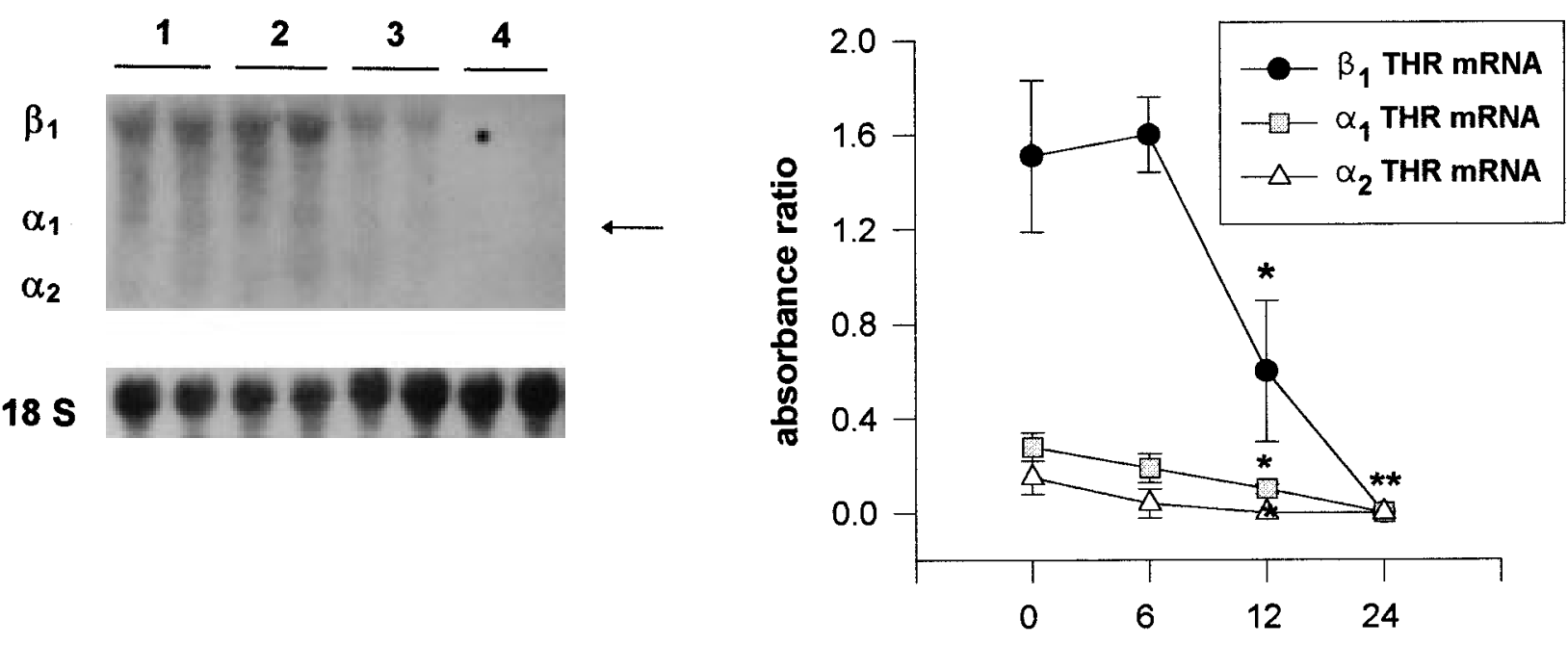

time (h) of rhIGF-I exposure

Figure 4 (A) Northern blot of rat liver $\beta_{1}, \alpha_{1}$, and $\alpha_{2}$ THR mRNAs after treatment with rhIGF-I (240 $\mu \mathrm{g} / 100 \mathrm{~g}$ BW) for 6, 12 and 24 h. Lanes 1 and 2: control; lanes 3 and 4: $6 \mathrm{~h}$; lanes 5 and 6: $12 \mathrm{~h}$; lanes 7 and 8: $24 \mathrm{~h}$. Forty micrograms of total RNA were applied to each lane. Blots were hybridized with THR (upper panel) and 18S rRNA probes (lower panel). Arrow indicates the $28 \mathrm{~S}$ rRNA marker. (B) Densitometric analysis of Northern blots. Data are given as the ratio between the absorbance of each specific THR signal and the absorbance of the 18S rRNA signal in the same lane. Data are from a representative experiment from a total of three with similar results. Results are expressed as means \pm S.D. Three samples were analysed from each individual animal in each group. ${ }^{*} P<0 \cdot 05,{ }^{* *} P<0 \cdot 01$ compared with the control group by one-way ANOVA followed by the Student-Newman-Keuls test. 
could not explain the inhibitory effect on the enzyme activities, because this effect was also seen in vitro in rat liver cells cultured with a fixed concentration of $\mathrm{T}_{3}(1 \cdot 0$ nM) (Pellizas et al. 1996). Moreover, when cells were incubated with $1 \mu \mathrm{M} \mathrm{T}_{3}$, a concentration large enough to saturate THRs fully (Mariash \& Oppenheimer 1983), the failure to reach the maximal $\alpha-G P D$ and ME activities in the group pre-exposed to IGF-I (Pellizas et al. 1996) suggested that the effect of IGF-I might not be related to alterations in nuclear occupancy by $\mathrm{T}_{3}$. Instead, such a response could involve a diminished number of functionally active nuclear $\mathrm{T}_{3}$ binding sites (Sato \& Robins 1981, Pellizas et al. 1996).

The magnitude of the cellular response to thyroid hormone depends on the abundance of nuclear receptors for $\mathrm{T}_{3}$. It is therefore possible that physiologically or pharmacologically induced alterations in receptor numbers may be able to modify the tissue response to $\mathrm{T}_{3}$ (Hodin et al. 1990). Previous reports indicate that, under several experimental conditions (DeGroot et al. 1977, Dillmann et al. 1978, Dillmann \& Oppenheimer 1979, Recúpero et al. 1983, 1986, Kaji \& Hinkle 1987), modifications in the number of THRs paralleled changes in the tissue response to thyroid hormone. Consequently, the diminished number of THRs induced by IGF-I treatment would explain, at least in part, the reduction in the metabolic response to $T_{3}$. However, in spite of the lack of known direct effects of IGF-I on $\alpha-G P D$ or ME, this possibility cannot be ruled out.

Although the amount of a specific protein cannot always be predicted on the basis of its mRNA level (Oppenheimer et al. 1995), the reduction in the concentrations of THR mRNAs after the administration of rhIGF-I $(240 \mu \mathrm{g} / 100 \mathrm{~g} \mathrm{BW}$ for $12 \mathrm{~h})$ may account for the reduction in the expression of THR proteins. Regarding the failure to detect THR mRNAs after the administration of 240 and $480 \mu \mathrm{g}$ rhIGF-I/100 g BW for $48 \mathrm{~h}$, and $240 \mu \mathrm{g} / 100 \mathrm{~g} \mathrm{BW}$ for $24 \mathrm{~h}$, it may be that the use of intermediate doses and times of exposure would produce progressive detectable reductions in THR mRNAs. The diminished amounts of liver mRNA coding for the $\beta_{1}, \alpha_{1}$ and $\alpha_{2}$ THRs suggest that the mechanism of IGF-I action could involve either a reduction in the rate of transcription of genes coding for the THR isoforms, or an increase in the rate of disappearance of the THR mRNAs. Moreover, an effect of IGF-I that is mediated by a reduction in stimulatory transcriptional factors or by enhanced inhibitory transcriptional factors of THR-coding genes should also be considered.

The possibility that the mechanism of action of IGF-I involves an increase in the $\alpha_{2}$ THR mRNA coding for a THR protein that lacks the ability to bind $\mathrm{T}_{3}$ and is known to inhibit the active THRs (Koenig et al. 1989) was disregarded, as $\alpha_{2}$ THR mRNA was concomitantly reduced.

The present results indicate that, in the rat liver, IGF-I modulates thyroid hormone action by a mechanism that involves, at least in part, an effect at the level of THR expression. Therefore, it is possible that IGF-I feeds back to limit the stimulatory action of $\mathrm{T}_{3}$ on IGF-I synthesis in liver cells (Ikeda et al. 1991), through THR downregulation.

Even though these effects of IGF-I were observed in experimental animals, our findings may have relevance to a possible impact on thyroid function in patients receiving GH or IGF-I treatment.

\section{Acknowledgements}

The authors are grateful to Dr Mirta Miras for kindly providing the recombinant human IGF-I and to Dr Liliana Franchioni-Muñoz for her excellent assistance with these studies.

Part of these studies was presented at the XI International Thyroid Congress, Toronto, Canada 1995 (Abstract 339) and the VII Latin America Thyroid Society Congress, Viña del Mar, Chile 1997 (abstract 19). This work was supported by grants from the Consejo de Investigaciones Científicas y Tecnológicas de la Provincia de Córdoba (CONICOR), Secretaría de Ciencia y Tecnología de la Universidad Nacional de Córdoba (SECyT), and Consejo Nacional de Investigaciones Científicas y Técnicas (CONICET), Argentina. C G P is a Fellow at CONICET.

\section{References}

Bernal J \& DeGroot LJ 1977 Thyroid hormone receptors: release of receptor to the medium during in vitro incubation of isolated rat liver nuclei. Endocrinology 100 648-655.

Bernal J, Coleoni AH \& DeGroot LJ 1978a Triiodothyronine stimulation of nuclear protein synthesis. Endocrinology 102 452-459.

Bernal J, Coleoni AH \& DeGroot LJ $1978 b$ Thyroid hormone receptors from liver nuclei: characteristics of receptor from normal, thyroidectomized, and triiodothyronine-treated rats; measurement of occupied and unoccupied receptors, and chromatin binding of receptors. Endocrinology 103 403-413.

Brent G 1994 The molecular basis of thryoid hormone action. New England Journal of Medicine 331 847-853.

Burton K 1956 A study of the conditions and mechanism of the diphenylamine reaction for the colorimetric estimation of deoxyribonucleic acid. Biochemical Journal 62 315-323.

Chamba A, Neuberger J, Strain A, Hopkins J, Sheppard MC \& Franklyn JA 1996 Expression and function of thyroid hormone receptor variants in normal and chronically diseased human liver. Journal of Clinical Endocrinology and Metabolism 81 360-367.

Chomczynski P \& Sacchi N 1987 Single-step method of RNA isolation by acid guanidinium thiocyanate-phenol-chloroform extraction. Analytical Biochemistry 162 156-159.

DeGroot LJ, Coleoni AH, Rue PA, Seo H, Martino E \& Refetoff S 1977 Reduced nuclear triiodothyronine receptors in starvationinduced hypothyroidism. Biochemical and Biophysical Research Communications 79 173-178.

DeGroot LJ, Stillabower GM, Ichikawa K, Coleoni A \& Darling D 1988 Binding of thyroid hormone receptor-associated factors to rat growth hormone gene $5^{\prime}$ flanking sequences. Molecular and Cellular Endocrinology 57 123-129. 
De Lean A \& Rodbard D 1979 Kinetics of cooperative binding. In The receptors: a comprehensive treatise, pp 143-192. Ed RD O'Brien. New York: Plenum Press.

Dillmann WH \& Oppenheimer JH 1979 Glucagon influences the expression of thyroid hormone action: discrepancy between nuclear triiodothyronine receptor number and enzyme responses. Endocrinology 105 74-79.

Dillmann WH, Schwartz HL \& Oppenheimer JH 1978 Selective alterations in hepatic enzyme response after reduction of nuclear triiodothyronine receptor sites by partial hepatectomy and starvation. Biochemical and Biophysical Research Communications 80 259-266.

Fourney RM, Miyakoshi J, Day III RS \& Paterson MC 1988 Northern blotting: efficient RNA staining and transfer. Focus 10 $5-7$.

Gosteli-Peter M, Winterhalter K, Schmid C, Froesch E \& Zapf J 1994 Expression and regulation of insulin-like growth factor-I (IGF-I) and IGF-binding protein messenger ribonucleic acid levels in tissues of hypophysectomized rats infused with IGF-I and growth hormone. Endocrinology 135 2558-2567.

Grunfeld C, Sherman BM \& Cavalieri RR 1988 The acute effects of human growth hormone administration on thyroid function in normal men. Journal of Clinical Endocrinology and Metabolism 67 1111-1114.

Gruppuso PA, Walker TD \& Carter PA 1991 Ontogeny of hepatic type I insulin-like growth factor receptors in the rat. Pediatric Research 29 226-230.

Harakawa S, Yamashita S, Tobinaga T, Matsuo K, Hirayu H, Izumo M, Nagataki S \& Melmed S 1990 In vivo regulation of hepatic IGF-I messenger ribonucleic acids with thyroid hormone. Endocrinologia Japonica 37 205-211.

Hervas EB, Morreale de Escobar G \& Escobar Del Rey F 1975 Rapid effects of single small doses of L-thyroxine and triiiodo-L-thyronine on growth hormone, as studied in the rat by radioimmunoassay. Endocrinology 97 91-101.

Hinton P, Peterson C, Lo H, Yang H, McCarthy D \& Ney D 1995 Insulin-like growth factor I enhances immune response in dexamethasone-treated or surgically stressed rats maintained with total parenteral nutrition. Journal of Parenteral and Enteral Nutrition 19 444-452.

Hodin RA, Lazar MA \& Chin WW 1990 Differential and tissue-specific regulation of multiple rat c-erb A messenger RNA species by thyroid hormone. Journal of Clinical Investigation $\mathbf{8 5}$ 101-105.

Hsu RY \& Lardy HA 1969 Malic enzyme. Methods in Enzymology 13 230-235.

Ikeda T, Fujiyama K, Hoshino T, Tanaka Y, Takeuchi T, Mashiba H \& Tominaga M 1991 Stimulating effect of thyroid hormone on insulin-like growth factor I release and synthesis by perfused rat liver. Growth Regulation 1 39-41.

Jaeggi-Groisman SE, Keller S, Zimmerli B, Meier PJ \& Froesch ER 1990 Polar surface distribution of type II insulin-like growth factor receptor in rat hepatocytes. Molecular and Cellular Endocrinology $\mathbf{7 4}$ 69-74.

Jones J \& Clemmons D 1995 Insulin-like growth factors and their binding proteins: biological actions. Endocrine Reviews 16 3-34.

Jorgensen JOL, Pedersen SA, Laurberg P, Weeke J, Skakkebaek EN \& Christiansen JS 1989 Effects of growth hormone therapy on thyroid function of growth hormone-deficient adults with and without concomitant thyroxine-substituted central hypothyroidism. Journal of Clinical Endocrinology and Metabolism 69 1127-1132.

Jorgensen JOL, Moller J, Laursen T, Orskov H, Christiansen JS \& Wecke J 1994 Growth hormone administration stimulates energy expenditure and extrathyroidal conversion of thyroxine to triiodothyronine in a dose-dependent manner and suppresses circadian thyrotrophin levels: studies in GH-deficient adults. Clinical Endocrinology 41 609-614.
Kaji H \& Hinkle PM 1987. Epidermal growth factor decreases thyroid hormone receptors and attenuates thyroid hormone responses in $\mathrm{GH}_{4} \mathrm{C}_{1}$ cells. Endocrinology 120 537-543.

Klinger B, Ionesco A, Anin S \& Laron Z 1992 Effect of insulin-like growth factor I on the thyroid axis in patients with Laron-type dwarfism and healthy subjects. Acta Endocrinologica 127 515-519.

Koenig RJ, Brent GA, Warne RL, Larsen PR \& Moore DD 1987 Thyroid hormone receptor binds to a site in the rat growth hormone promoter required for induction by thyroid hormone. Proceedings of the National Academy of Sciences of the USA $\mathbf{8 4}$ $5670-5674$.

Koenig RJ, Warne RL, Brent GA, Harney JW, Larsen PR, Moore DD 1988 Isolation of a cDNA clone encoding a biologically active thyroid hormone receptor. Proceedings of the National Academy of Sciences of the USA 85 5031-5035.

Koenig RJ, Lazar MA, Hodin RA, Brent GA, Larsen PR, Chin WW \& Moore DD 1989 Inhibition of thyroid hormone action by a non-hormone binding c-erbA protein generated by alternative mRNA splicing. Nature 337 659-661.

Kolaczynski J \& Caro J 1994 Insulin-like growth factor I. Therapy for diabetes mellitus? Diabetes Care 17 92-96.

Lee YP \& Lardy HA 1965 Influence of thyroid hormones on L- $\alpha-G P D$ and other dehydrogenases in various organs of the rat. Journal of Biological Chemistry 240 1427-1436.

Lemmey AB, Glassford J, Flick-Smith HC, Holly JMP \& Pell JM 1997 Differential regulation of tissue insulin-like growth factor-binding protein (IGFBP)-3, IGF-I and IGF type 1 receptor mRNA levels, and serum IGF-I and IGFBP concentrations by growth hormone and IGF-I. Journal of Endocrinology 154 319-328.

Lo H, Hinton P, Peterson C \& Ney D 1995 Simultaneous treatment with IGF-I and GH additively increases anabolism in parenterally fed rats. American Journal of Physiology 269 E368-E376.

Mariash CN \& Oppenheimer JH 1983 Interrelationship of triiodothyronine concentration, metabolism, protein binding, and nuclear occupancy in the induction of malic enzyme by cultured adult rat hepatocytes. Endocrinology 112 80-85.

Mariash CN, Kaiser FE, Schwartz HL, Towle HC \& Oppenheimer JH 1980 Synergism of thyroid hormone and high carbohydrate diet in the induction of lipogenic enzymes in the rat. Mechanisms and implications. Journal of Clinical Investigation 65 1126-1134.

Massagué J \& Czech MP 1982 The subunit structures of two distinct receptors for insulin-like growth factor I and II and their relationship to the insulin receptor. Journal of Biological Chemistry $2575038-5045$.

Melmed S \& Yamashita S 1986 Insulin like growth factor-I action on hypothyroid rat pituitary cells: suppression of triiodothyronine-induced growth hormone secretion and messenger ribonucleic acid levels. Endocrinology 118 1483-1490.

Nanto-Salonen K, Muller HL, Hoffman AR, Vu TH \& Rosenfeld RG 1993 Mechanisms of thyroid hormone action on the insulin-like growth factor system: all thyroid hormone effects are not growth hormone mediated. Endocrinology 132 781-788.

Nyborg JK, Nguyen AP \& Spindler SR 1985 Cyclic regulation of growth hormone gene transcription in vivo and in vitro. Endocrinology 116 2361-2365.

Oppenheimer JH, Schwartz HL \& Strait KA 1995 An integrated view of thyroid hormone actions in vivo. In Molecular Endocrinology: basic concepts and clinical correlations, pp 249-268. Ed BD Weintraub. New York: Raven Press.

Pellizas C, Coleoni A, Cabanillas A, Masini-Repiso A \& Costamagna M 1996 Response of triiodothyronine-dependent enzyme activities to insulin-like growth factor I and growth hormone in cultured rat hepatocytes. European Journal of Endocrinology 134 215-220.

Raper S, Kothary P, Ishoo E, Dikin M, Kokudo N, Hashimoto M \& DeMatteo RP 1995 Divergent mechanisms of insulin-like growth factor I and II on rat hepatocyte proliferation. Regulatory Peptides $\mathbf{5 8}$ $55-62$. 
Recúpero AR, Coleoni AH, Cherubini O \& Oviedo A 1983 Selective alterations in hepatic nuclear $\mathrm{T}_{3}$-receptors and enzyme responses by glucocorticoid deficit or excess. Acta Endocrinologica 104 485-489.

Recúpero AR, Coleoni AH, Cherubini O \& Oviedo A 1986 Relationship between the increase in liver nuclear triiodothyroninereceptor sites and malic enzyme activation by dexamethasone. Acta Physiologica et Pharmacologica Latinoamericana 36 93-103.

Rodriguez-Arnao J, Miell JP \& Ross RJM 1993 Influence of thyroid hormones on the GH-IGF-I axis. Trends in Endocrinology and Metabolism 4 169-173.

Sato K \& Robbins J 1981 Thyroid hormone metabolism in primary cultured rat hepatocytes. Effect of glucose, glucagon, and insulin. Journal of Clinical Investigation 68 475-483.

Scatchard G 1949 The attraction of proteins for small molecules and ions. Annals of the New York Academy of Science 51 660-672.

Schwartz HL, Strait KA, Ling NC \& Oppenheimer JH 1992

Quantitation of rat tissue thyroid hormone binding receptor isoforms by immunoprecipitation of nuclear triiodothyronine binding capacity. Journal of Biological Chemistry 267 11794-11799.

Strait KA, Schwartz HL, Perez-Castillo A \& Oppenheimer JH 1990 Relationship of c-erb A mRNA content to tissue triiodothyronine nuclear binding capacity and function in developing and adult rats. Journal of Biological Chemistry 265 10514-10521.

Venkatesan N \& Davidson MB 1990 Insulin-like growth factor I receptors in adult rat liver: characterization and in vivo regulation. American Journal of physiology 258 E329-3337.

Williams GR \& Brent GA 1995 Thyroid hormone response elements. In Molecular Endocrinology: basic concepts and clinical correlations, pp 217-239. Ed BD Weintraub. New York: Raven Press.

Wilson EJ \& McMurray WC 1981 Regulation of malic enzyme and mitochondrial $\alpha$-glycerophosphate dehydrogenase by thyroid hormones, insulin and glucocorticoids in cultured hepatocytes. Journal of Biological Chemistry 256 11657-11662.

Yamamoto H, Sohmiya M, Oka N \& Kato Y 1991 Effects of aging and sex on plasma insulin-like growth factor I (IGF-I) levels in normal adults. Acta Endocrinologica 124 497-500.

Yen P \& Chin W 1994 New advances in understanding the molecular mechanisms of thyroid hormone action. Trends in Endocrinology and Metabolism 5 65-72.

Received 2 October 1997

Revised manuscript received 16 December 1997 Accepted 16 February 1998 